\title{
Inclusive Education: A Literature Review on Definitions, Attitudes and Pedagogical Challenges
}

\author{
Tebatso Namanyane, Md Mirajur Rhaman Shaoan \\ Faculty of Education Southwest University China \\ DOI: https://dx.doi.org/10.47772/IJRISS.2021.5324
}

\begin{abstract}
This paper on inclusive education explores several diverse viewpoints from various scholars in different contexts on the concepts of inclusive education in an effort to reach the common understanding of the same this concept. The attitudes section is addressed from the perspectives of pupils, educators, and the society (parents), and it further explore the dilemmas that teachers and students with disabilities face in modern education systems. The instructional approaches focusing on how teachers plan and execute lessons with diverse students' aptitudes from literature are also levelheadedly outlined. In conclusion, it included a broad overview focused on two models, social and medical models on which this paper is primarily based.
\end{abstract}

Key words: Inclusive Education, Attitudes, Pedagogical Challenges

\section{INTRODUCTION}

$\mathrm{T}$ here are several terms in the field of education that are interpreted differently depending on the reason for which they are meant. Others have been given meanings that are globally recognized, while others are interpreted differently based on the varying reasons and factors affecting them, including religion and regions, history, values, race, and resource limitations. The present paper is intended to discuss an interesting educational topic which has intrigued scholars across the globe due to its arguable definitions from different perspectives. It will also have a more comprehensive but remarkably different interpretation of these core tenets as proposed in the topic specified above, Inclusive Education: A Literature Review on Definitions, Attitudes and Pedagogical Challenges. Education is a full process of training a new generation who is ready to participate in civic life and is also a vital link in the process of human social production experience to be carried out, with special regard to the process of school education for school-age infants, young people and retired people. Generally, all things that will improve human intelligence and skills and affect people's moral character as considered as part of education. In a narrow sense, it is primarily schooling, which is characterized as the practice of educators to impact the mind and body of the learner intentionally, purposefully and systematically according to the requirements of a specific community or class to develop them as persons they want to be. Aristotle defines education as the way to prepare a man to achieve his mission by exercising all the faculties to the fullest degree as a citizen of society. And Professor Yunus define education as any initiative that is purposefully selected to impact and assist children with the purpose of enhancing awareness, physical and values that will eventually bring the child to the highest target. In order that the child will live a happier life, that all that he has done will be beneficial to himself and to society. While briefly Dewey (1978) articulates that "education is all one with growing; it has no end beyond itself."It could well be recognized that, from the time of Aristotle, there are different definitions of education that have common ideas among them, that education must cultivate people as individuals who are autonomous, as well as train them to thrive in and for the society in which they live. This idea provokes the field of education to make a recurring evaluation and thus, different concepts emerged; Free Primary Education, Education for all, Education for Sustainable Development, Inclusive Education, and others. However, as mentioned earlier, the discussion of this paper will only pay attention on one concept, Inclusive Education (IE).

Inclusive Education, as one of the scholarly concepts, appears to lack a globally agreed meaning even though attempts have been made across vast literature. According to Shyman (2015) capturing the concept IE as both an educational principle and a practical application is far more than intellectually challenging. It is among the most wearisome tasks of all academic pursuits within the field of education. This is because IEon its own, is an exceptionally broad term encompassing all individuals to one degree or another, efforts to define it requires both broad strokes and wide applications while still maintaining very specific verbiage(Shyman, 2015).This situation is caused by different laws, beliefs, inefficient resources, and cultural practices in different countries. The National Center on Educational Restructuring and Inclusion (NCERI, 1995), considers inclusion as "the provision of services to students with disabilities, including those with severe impairments, in the neighborhood school, in age-appropriate general education classes with the necessary support services and supplementary aids (for the child and the teacher) both to assure the child's academic success, behavioral, social and to prepare the child to participate as a full and contributing member of the society" (NCERI, 1995:3). This definition can be seen as detailed in the way that it stresses the consistency and placement of educational facilities, as well as the school-wide viewpoint. This definition will definitely be considered representative of a full inclusion model, but it applies a far relatively mild language than most full inclusion definitions. According to Idol (2006) 
inclusion is "when a pupil with additional academic and/or behavioral needs is professionally trained in the general education curriculum. Essentially, inclusion ensures that children with special education needs attend the general school curriculum and are enrolled in age-appropriate classrooms $100 \%$ every school day" (Idol, 2006:4).Furthermore, the international organizations such as United Nations Educational, Scientific and Cultural Organizations (UNESCO) and United Nations International Children's Emergency Fund (UNICEF) supporting education at international level, attempts have been made to match their criteria and unique definitions with different definitions and models in an attempt to define inclusive education.

UNESCO supported by other UN-based organizations as well as 92 governments and 25 international organizations experiential and social issues of those with exceptionalities internationally became a focal point. The main message of the agreement was to bolster the international effort in making social and educational inclusion the normal practice for individuals with exceptionalities on a global level. The agreement stated: All governments are to give the highest policy and budgetary priority to improve education services so that all children could be included, regardless of differences or difficulties. They should adopt as a matter of law or policy the principle of inclusive education and enroll all children in ordinary schools unless there were compelling reasons for doing otherwise; develop demonstration projects and encourage exchanges with countries with inclusive schools; ensure that organizations of disabled people, along with parents and community bodies, put greater effort into preschool strategies as well as vocational aspects of inclusive education; Ensure that both initial and in-service teacher training address the provision of inclusive education (UNESCO, 1994). While UNICEF (2017), explain inclusive education in terms of how education system should be;"An education system that includes all students, and welcomes and supports them to learn, whoever they are and whatever their abilities or requirements. This means making sure that teaching and the curriculum, school buildings, classrooms, play areas, transport and toilets are appropriate for all children at all levels. Inclusive education means all children learn together in the same schools" (UNICEF, 2017:1).

The following models are adapted from UNICEF (2017) online paper and they show the rights of the children with

Requirements to make inclusive education happen (UNICEF 2017)

- An end to discrimination

- An end to excluding children with disabilities

- Access to primary and secondary education with sufficient numbers of accessible and inclusive schools, including for children with disabilities caught in crisis and emergencies. disability that governments should consider figure 1, and the framework of what needs should bemirroredin education systems which includes children with disabilities, figure 2 .

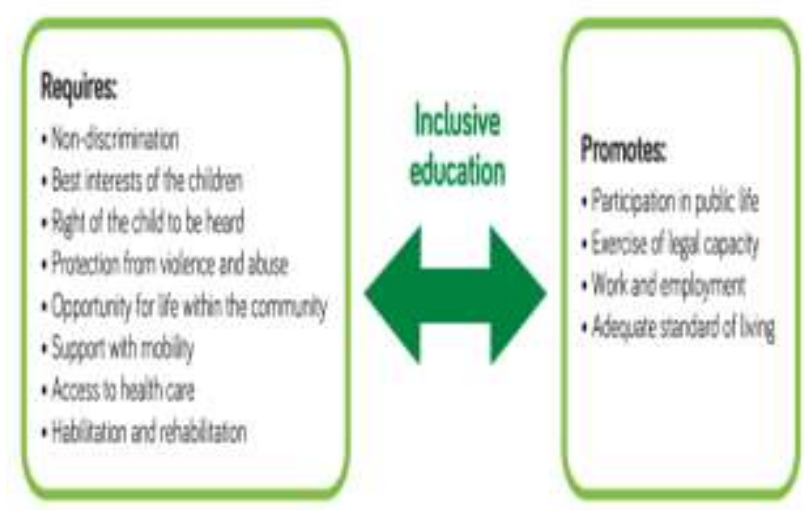

Figure 1: Adapted from UNICEF (2017), Outline of what IE requires and promotes.

Inclusive education systems: Inclusive education involves transforming the whole education system - legislation and policy, systems for financing, administration, design, delivery and monitoring of education, and the way schools are organized (UNICEF, 2017),figure 2.

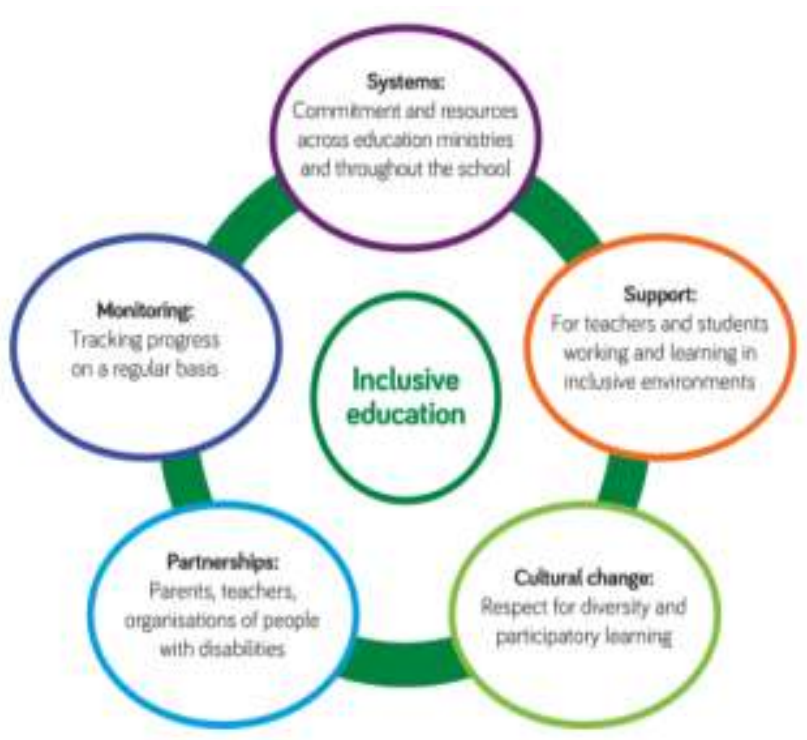

Figure 2: A Framework of IE adapted from UNICEF (2017) in schools.

- Practical support or adaptations for students to enable them to learn this is called 'reasonable accommodation.'

- Individual education plans for children with disabilities setting out what accommodations and support they need.

- Services for specific impairments such as learning braille or sign language, classroom reorganization and accessible learning materials.

- Teachers adequately trained to work in inclusive schools. 
In the Organization for Economic Co-operation and Development (OECD) (1999), report it is claimed that there is an agreement about what inclusive education is, and that the main challenges for globally accepted definition are the combination resulting from lack of political will and human beings' endless resistance to change (OECD, 1999).In spite of an overriding formal normative consensus between organizations, even scholars have acknowledged that it tiring to reach consensus .It is not possible to find one universally institutionalized definition of inclusive education, therefore, it is premature to draw any conclusion about agreement(Haug, 2017). Moreover, for a long time there has been a battle about the interpretation of the concept of inclusion (Hansen \& Qvortrup, 2013). The importance of this contest about its meaning is that definitions both reflect the understanding and affect the practicing of the concept and, in turn, how inclusive education meets and treats different groups of students. Different meanings create tensions. To systematize and discuss the differing understandings involved could represent a richness in the development of inclusive education (Florian, 2014; cited in Haug, 2017).

Among these definitions of inclusion/Inclusive Education, this paper will adopt broader definitions proposed by Thomas (2013) and UNESCO (1994) documents. Thomas' (2013) definition of inclusion concerns'all students' and 'marginalized groups', not only those with disabilities. It is in line with the Salamanca's Declaration from 1994, which covers all groups of students in danger of facing problems in school because of diversity (UNESCO, 1994). The declaration concerns all students at risk of discrimination and their capacity to interact in normal learning experiences within the ordinary school system, irrespective of their particular needs, gender, race, culture, and social context. The other important concept to be considered in this paper is 'attitudes' towards inclusion from teachers', students', and parents/community's perspectives. According to Smith (1971) an attitude is a relatively enduring organization of beliefs around an object, person, or a situation, predisposing one to respond in some preferential manner, it can be learned or changed depending on different situations. "Attitudes are psychological tendencies that are expressed by evaluating a particular entity with some degree of favor or disfavor" (Eagly \& Chaiken, 1993:1). Attitudes have also been described byHogg and Vaughan (2005), as"a relatively enduring organization of beliefs, feelings, and behavioral tendencies towards socially significant objects, groups, events or symbols" (Hogg \& Vaughan, 2005:150). They are basically divided into three components build in a model also known as ABC Model of Attitudes:a) Affective; involves a person's feelings/ emotions about the attitude object. b) Behavioral; the way the attitude we have influences on how we act or behave.b) Cognitive component; involves a person's belief and knowledge about an attitude object(Katz, 1960).Figure 3 shows an ABC Model discussed in Eagly and Chaiken (1993).

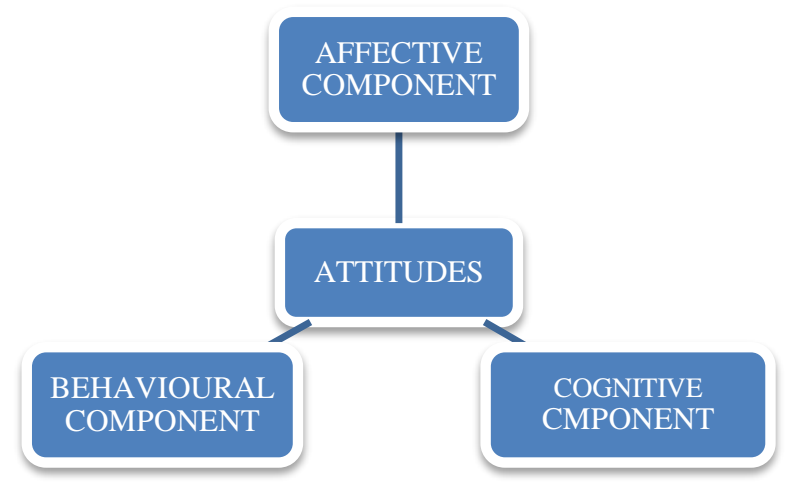

Figure 3: Eagly \& Chaiken (1993), ABC Model of attitudes

In this papers, attitudes towards inclusion that will be discussed will be teachers' attitudes towards inclusive education in general, students attitudes towards inclusive education, parents/community attitudes towards inclusive education and students-students attitudes (referring to students attitudes towards other students with disabilities). The last concept to be reviewed in this opening section is pedagogy definitions. From the behaviorist's point of view, Thorndike (1911), Pavlov (1927) and Skinner (1957) pedagogy is the theory that the teacher should be the sole authority figure and leads the lesson. Knowledge should be delivered in a curriculum where each subject is taught discretely. While according to Steele, Holbeck and Mandernach (2019:5) "pedagogy includes virtually any strategy that enhances the learning experience(including instructional strategies, interaction with technology, vehicles for content delivery,etc.), and emphasizes the context and interactions of the teaching and learning dynamic.'In a lesson using a behaviorist pedagogical approach, a teacher is expected to be able to use a combination teaching method which may include, lecturing, modelling and demonstration, rote learning, and choral repetition. These activities can be 'visible' and should be structured by the instructor. However, as the lesson or class session continues, the shift towards students-centered classroom activities dominates. Other theories related to pedagogy are constructivism theory Piaget (1896-1890), which emphasize that Constructivist pedagogy puts the child at the center of the learning and is sometimes called 'invisible pedagogy'. A constructivist approach would incorporate project work, inquiry-based learning. Social constructivism by Lev Vygotsky argued against the ideas of Piaget that learning could only happen in its social context and believed that learning was a collaborative process between student and teacher. Finally, liberationism which is a critical pedagogy developed by the Brazilian educator, Paulo Freire. A liberationist approach is one where the student's voice is placed at the center, and a democracy is put into the classroom. Value is placed on having the teacher as a learner too, and the class discovering subjects together. Teachers may use examples of literature that include non-standard 
constructions, such as hip-hop or graffiti. Students will take on the role of the teacher and decide on the subject of the lesson. Teachers can have a platform and an ability for students to demonstrate their learning, and this can take the form of presentation, monologue, or dance in a classroom environment.

\section{Teacher's Attitudes towards Inclusive Education}

Teachers are currently responsible for teaching increasingly ethnically and linguistically diverse classes but are also more accountable forac commodating students with Special Educational Needs (SEN) in regular classes (OECD, 2012). This section will address teacher attitudes towards IE on the basis of various environments and different resources and assistance in different countries, so it should be assumed that the expectations of the next review will vary very differently, providing brief details depending on the context, methodologies used and sampling methods, including the sample size of the studies conducted under the IE umbrella. In the past couple of decades, the understanding of special education in all communities has shifted. Instead of segregating children with special needs in special classrooms and schools, the dogma behind Inclusive Education proposes that programs must be tailored to meet the needs of all pupils. The school systems are responsible for providing children with special needs adequate education. However, the idea of inclusion seems to be a major challenge in many countries (Flem \& Keller, 2000, Haug, 1999, Snyder, 1999, Hughes, Schumm \& Vaughn, 1996; all cited in Al-Zyoudi, 2006).Even though this is the reality, many nations tend to be making attempts to include students with disabilities in their education systems through the implementation of education programs, regulations, and schools reform processes. For example, the country Lesotho, found in Southern Africa, there are policies implemented by Ministry of Education (MoET) that students from needy families, children with disabilities and orphans should have access to high-quality education, with tuition and other school conditions being compensated by the state. Moreover, in 1989, the MoET in the mentioned country developed a policy statement outlining provisions and their shortcomings. The seven goals of the policy statement were that the Ministry of Education would: (1) advocate for integrating people with disabilities into the mainstream school system; (2)establish resource centers to assess learners' needs and prepare them for integration; (3) ensure that all people with disabilities complete the seven year primary education; (4) establish a functional itinerant special education team to support mainstream teachers; (5) create a network of services that would enable the education of people with disabilities; (6) respect the rights of children with disabilities not to be displaced but to live with parents or legal guardians; and(7) include special education programmes into pre-service teacher training(Ministry of Education, 1989; cited in Mosia, 2014).This study conducted by Mosia (2014), used a purposive sample of $n=10$,in Lesotho and the findings show that teachers have negative attitudes towards inclusive education due to irrelevant in-service training, poor leadership from school principals, time constrains between lessons as well inefficient knowledge on teaching approaches to include all students with different disabilities (Mosia, 2014). Lack of support and transparency from the government through MoET emerged as the other factor causing negative attitude among teachers towards inclusive education in the country.

However, in other contexts, teachers appear to have the opposite attitudes as compare to the context discussed above (Lesotho). In the other context, a qualitative phenomenological study conducted by Zelina (2020) in Slovakia used sample consisted of $n=218$ female teachers with a minimum of $20 \%$ of disadvantaged students in their classroom. The main findings show that the teachers' opinions and attitudes towards inclusive education are positive and they appreciate their cooperation with specialists in schools. The research revealed some barriers to the realization of inclusive education for example, the disadvantaged children's poor school attendance or their general unpreparedness for school (Zelina, 2020). Moreover, the participants called for more favorable conditions ensured by the state and early address of the newly emerging problems facing inclusion in schools. Engelbrecht, Savolainen, Nel, and Malinen (2013) showed how teachers' attitudes towards IE in Finland and South Africa are mediated by each country's historical commitment to IE and how education has responded to diversity in the past. Thus, the way a universal idea is enacted in practice locally varies, and to understand these realities, more comparative research is needed to inform decision-making on IE (Kozleski, Artiles, Fletcher, \& Engelbrecht, 2007).Moberg, Muta, Korenaga, Kuorelahti and Savolainen (2019) conducted a quantitative study to analyze and compare teachers' attitudes towards IE in Japan and Finland, the two culturally different countries. These scholars used sample of 362 Finnish and 1518 Japanese teachers $(n=1880)$,in their survey. The teachers' attitudes towards IE were measured with a scale designed by Moberg (1997) and used by Moberg and Savolainen (2003). The scale consists of 19 statements on a six-point Likert scale. The statements represent the major features of the debate over inclusion.The teachers' attitudes varied and were rather critical. The Finnish teachers were more worried about teachers' efficacy when implementing inclusion, particularly when teaching students with intellectual disabilities or emotional and behavioral problems. The Japanese teachers had a more positive view on the benefits of inclusion for disabled or non-disabled students(Moberg et al., 2019).

Some researchers believe that the foundations of positive, equitable and inclusive attitudes towards education of students with disabilities is highly dependent on preservice-teacherpreparation programmes because new teachers, who find themselves struggling with the complex demands and challenges of the inclusive classroom, mostly criticize lack of satisfactory preparation as one source of their frustration (Horne \& Timmons, 2009, Loreman, 2010, Sosu, Mtika,\& 
Colucci-Gray, 2010; all cited in Killoran, Woronko \& Zaretsky, 2014).In 2006, Sunko (2006) analyzed the curricula employed in different higher education institutions in the Republic of Croatia, the results showed significant differences in the attitudes of pre-service students whose study programs had inclusive values from those who mostly were not exposed to such contents (Sunko, 2006).In different geographical locations and contexts, teachers have the compelling sense that they have disparate views towards inclusive education, and there are reasons that are related to this manifestation, some of which have only been checked. This experience confirms the unrest in the concept IE. It is also necessary to remember that the contextualized meaning of this term (IE) is important and will help teachers develop healthy attitudes towards IE, along with the necessary assistance received by teachers in various education systems. The next section will reflect on student attitudes towards IE and attitudes of peer students in inclusive school settings.

\section{STUDENTS' ATTITUDES TOWARDS INCLUSIVE EDUCATION}

In the 1980s, inclusion became part of an education reform initiative worldwide that demanded full participation of children with disabilities in regular education. However, how schools ought to ensure full participation was intimately bound up in the cultural milieu of schools and the attitudes of principals, teachers, and non-disabled children. It was therefore necessary for researchers to understand how the views, beliefs and attitudes of nondisabled children could influence the full participation of disabled children (Blackman, 2016). Nowicki and Sandieson (2002) claimthat negative attitudes among students not only prevent them from participating in school, but they lead to a more serious problems and bad habits likebullying, deterioration in academic performance and high drop-out rate in schools (Nowicki \& Sandieson, 2002; cited inBlackman, 2016). In this sense, it can be deduced that students' social relationships in schools with disabled children needs to be well monitored and regularly assessed by educational leaders, researchers, and other stakeholders. In Netherlands, Koster, Nakken, and Houten (2010) conducted a survey study $(n=600)$, primary school children, including students with a range of impairments, to study how well disabled children were socially integrated in their schools. The finding of this study shows that, while other students participated in social life in their schools' environment, children with disabilities could not enjoy the same level of social participation as their peers without disabilities (Koster et al., 2010). The conclusion made by these scholars is that children with disability could not easily make and maintain friendships with others, their social interactions with other students was not satisfying because they were less accepted (Koster et al., 2010).

A meta-analysis of twenty studies on the attitudes of children with disabilities from a number of European countries, Korea, the United States of America (USA) and Canada by de Boer, Pijl and Minnaert(2012) concise over ten years of attitudinal research on students' IE. The findings on gender and age as cited by de Boer et al. (2012). They cite Swaim and Morgan's study (2001) which investigated the attitudes of $n=233,8-12$ yearold towards their peers with severe intellectual impairment in USA. Findings presented that younger students have more positive attitudes towards peers with intellectual impairment than older pupils (cited in Koster et al., 2010).According to Markova, Cate, and Krolak-Schwerdt (2015) in Germany, students with immigrant backgrounds experience inequalities in educational attainment and placements and in their academic prospects. One fifth of the German population has a recent immigrant background, and the largest groups of immigrants are people from southeastern Europe, especially Turkey (20.4\% of the foreign population under the age of 20) (Markova et al., 2015). However, students in inclusive or regular classes may have similar attitudes, the involvement, contact, and participation in joint activities assume a determinant role in this issue(Schwab 2017).

\section{COMMUNITY/PARENTS' ATTITUDES TOWARDS INCLUSION}

When an infant is born, the first people to communicate with are the parents, then the community, until they go to formal education. It is at this point that personalities can evolve based on the child's characteristics. Later on, as a child goes to formal education, interacts more with peers and teachers than with parents, and the way in which they communicate, as outlined in national or school policy, will create questions about both parents and the society, so behaviors will arise. This section will cover the literature on parents/community perspectives on inclusive education. According to Vorapanya and Dunlap (2014), some families may feel a sense of guild over having a child with disabilities. This feeling or attitude may result inparents being in denial regarding the differently abled condition of their child or relative.

Parents have a power to decide whether their children with disabilities should be included in the mainstream school setting. This is because parents are believed to be integral partners in developing a more inclusive system where in, they share the responsibility of decision-making and its consequences (Swart, Engelbrecht, Eloff, Pettipher, \& Oswald, 2004).It has also been noted that while some parents are positive towards inclusive practices, others have reservations regarding the same(Sharma, 2019). Bullying, victimization, social isolation, and rejection are some of the key concerns in mainstream classes of parents for their children with SEN (Kasari et al.,1999; Leyser \& Kirk, 2004; cited in Sharma, 2019).Moreover, parents who are not favoring inclusive classrooms are concerned about the school settings and teachers' attitudes. They argue that regular education settings cannot accommodate their children and that teachers could be burdened with inclusion of students with disabilities in their classes (Green \& Shinn, 1994; Kavale \& Mostert,2004).Parents are primarily concerned with the class size and teaching capabilities of the teachers to meet the 
demands of a diverse range of students. Parents also tend to have their doubts about the kind of training and experience that teachers have handling children with disabilities, and the schools lacking the resources and provision to educate their children properly(Grove \& Fisher, 1999).

However, other studies found that some parents with children without SEN have positive attitudes towards inclusion such as Purdue (2006). Parents have also reported that exposure to diversity in inclusive education helps their young ones demonstrate more open-mindedness and acceptance towards individual differences(Peetsma, 2009).Schmidt, Krivec and Bastič(2020) conducted the study in Slovakia with the aim to examine parents' attitudes towards the constructs associated with pre-school inclusion using the cluster sampling method $n=296$ of which $n=85$ had children with SEN. The results showed that parents of children with SEN are more open to inclusion, perceived positive social effects and benefits for children with and without SEN and had fewer negative feelings about the inclusion effects on children without SEN, than parents of children without SEN(Schmidt et al., 2020). The subsequent analysis in the next category will dwell more on the pedagogical complexities in IE.

\section{PEDAGOGICAL CHALLENGES IN INCLUSIVE EDUCATION}

Nurturing inclusion with a diverse student body poses many challenges for teachers and school administrators(Juvonen, Lessard, Rastogi, Schacter \& Smith, 2019:255). Inevitably, younger individuals carry with them different personalities in a classroom where teachers have to work successfully with them. This is compounded by the fact that more disabled students are studying in classes, so teachers probably take longer and more effective skills to cope with diverse classes in terms of learning skills. Some students are fast learners, while others require more time and focus to cope with classroom activities to help them comprehend the content. The other barriers to inclusive pedagogy are the consequences of diverse traditions and standards present in different multicultural countries. This unit will address the pedagogical obstacles of inclusive education based on existing literature.

According to Haug (2010) and Vislie (2003), Inclusive education not only applies to pedagogy in groups or schools, but nations may have varying laws on inclusive education, but not inclusive practices in schools, or may have inclusive educational practices, but not inclusive policies (Haug, 2010; Vislie, 2003).However, the empirical evidence portrays that to be successful, both importers and exporters of inclusive philosophies must respect local values. This means that it is very challenging for a country and its schools over a short time period to implement an advanced inclusive policy when it is in contrast to established national traditions. Therefore, each country must develop its own path to inclusive education depending on their context (Mitchell, 2005). As a part of this process, it must also bring about its own understanding and perspectives concerning inclusive education. Without doubt, countries and schools can learn from each other through workshops and seminars on how best they can implement inclusive teaching strategies including assessments. It could be a temptation to copy definitions and approaches from the more experienced however there is a risk involved when indirectly importing inclusive solutions and strategies from others and, in that way, standardizing school systems may result. Moreover, if these solutions and strategies adapted from other schools and systems do not work, they could even make things worse (Haug, 2017).Teachers are inclined to spend more time on students who have behavioral problems or those who work at a slower pace(Shipley, 1995), thereby resulting in the lowering of the general academic standards of education(Huber et al., 2001). Good or higher performing students may also be at a risk of getting bored owing to the slow-paced teaching atmosphere in the classroom and they may be disappointed on discovering that other students, despite studying less, secure same or even better grades (Shipley, 1995).Lastly, even the instructional practices that distance groups are problematic as lack of cross-group interaction maintains stereotypes and negative attitudes(Allport, 1954; Pettigrew, 1998; cited in Juvonen et al., 2019).

\section{SUMMARY AND CONCLUSION}

In summary, children and people with disability are viewed differently by different groups of people they interact with in different contexts. This summary is not solely based on students with disabilities in schools rather, will be generally grounded from different perspectives on how people view disability. The discussion will be dominated by three models as an attempt to give a clear understanding on how actually different people based on different backgrounds view disability according to different models. Table 1 below outlines the distinctions between two models.

Table 1: McCain (2017) Medical model and Social models

\begin{tabular}{|c|c|c|}
\hline a & $\begin{array}{c}\text { Medical model } \\
\text { that disability is a } \\
\text { deficiency or abnormality. }\end{array}$ & $\begin{array}{c}\text { Social model } \\
\text { is a difference, just as a person's } \\
\text { gender, age or race is a difference. }\end{array}$ \\
\hline b & $\begin{array}{c}\text { The medical model } \\
\text { proposes that having a } \\
\text { disability is negative }\end{array}$ & $\begin{array}{c}\text { The social model says that having a } \\
\text { disability is neutral. It is a part of } \\
\text { who you are. }\end{array}$ \\
\hline c & $\begin{array}{c}\text { The medical model says } \\
\text { that the disability is in you } \\
\text { and it is your problem }\end{array}$ & $\begin{array}{c}\text { The social model portrays that } \\
\text { disability exists in the interaction } \\
\text { between the individual and society. } \\
\text { Disability issues stem from } \\
\text { someone with a disability trying to } \\
\text { function in an inaccessible society. }\end{array}$ \\
\hline d & $\begin{array}{c}\text { The social model argues that the } \\
\text { remedy is a change in the } \\
\text { medical cure or by trying to } \\
\text { make the person appear } \\
\text { less disabled or more } \\
\text { "normal". }\end{array}$ & $\begin{array}{c}\text { The medical model } \\
\text { anteraction between the individual } \\
\text { and society. When society changes } \\
\text { the issues of a person with a } \\
\text { disability disappear. If a building is } \\
\text { fully accessible it doesn't matter if a } \\
\text { person walks in, runs in, or comes } \\
\text { in with a wheelchair or walker. }\end{array}$ \\
\hline & $\begin{array}{c}\text { The social model, however, says } \\
\text { that the fix can be found within the }\end{array}$ \\
\hline
\end{tabular}




\begin{tabular}{|c|c|c|}
\hline $\begin{array}{c}\text { found with a professional. } \\
\text { The only person who can } \\
\text { help a person with a } \\
\text { disability fit into society, } \\
\text { and be accepted, is a } \\
\text { professional. }\end{array}$ & $\begin{array}{c}\text { individual with a disability or } \\
\text { anyone who wants people with } \\
\text { disabilities to be equally included in } \\
\text { society, }\end{array}$ \\
\hline
\end{tabular}

According to McCain (2017) People with disabilities have been told for so long that something is wrong with them, that they need to be cured, and that they should not be shocked that they are not completely accepted or allowed to engage in society. These derogatory messages are also internalized by people with disabilities and build even more obstacles to inclusion. However, more people with disabilities are finding their voices, and asserting their rights, all the while challenging the perceptions, definitions, and models of disability that currently exist(McCain, 2017). They are stating that we must move away from the medical model, which states that the person with the disability is the problem, towards the social model, which emphasizes that society itself has a responsibility to create inclusive communities (McCain, 2017). As the differences in the models are being shared and explained, people with disabilities are gaining support and understanding from others in society, politicians, city employees, advocates, non-profit organizations, medical professionals, and individuals within the community.

Finally, the other model to be briefly discussed in this concluding section is the Biopsychosocial Model proposed by Engel and Romano(1977)in the University of Rochester. In developing this model, Engel framed it for both peoples' illnesses and psychological problems. This model emphasizes a 'holistic' approach to disability by recognizing that each patient has his or her own thoughts, feelings, and history. When a society, teachers, educational leaders, and all other authoritative stakeholders in education have adequate knowledge about their students' needs (including special needs) and capabilities, they can be able to strategically design appropriate curriculum which includes suitable evaluation methods which will not be bias among students' differences and aptitudes.

\section{REFERENCES}

[1] Al-Zyoudi, M. (2006). Teachers' Attitudes Towards Inclusive Education in Jordanian Schools.International Journal of Special Education, 21(2).

[2] Blackman, S. (2016). Barbadian Students' Attitudes Towards Including Peers With Disabilities in Regular Education .International Journal of Special Education,31(1).

[3] Flem, A. \& Killer, C. (2000). Inclusion in Norway: a study of ideology in practice. European Journal of Special Needs Education, 15(2), 188-205.

[4] Florian, L. (2014). "What Counts as Evidence of Inclusive Education?" European Journal of Special Needs Education 29(3), 286-294.

[5] Grove, K.A. \& Fisher, D. (1999). Entrepreneurs of meaning: Parents and the process of inclusive education. Remedial and Special Education, 20, 208-15.

[6] Hansen, O., \& Qvortrup,L. (2013). "Inclusions Danmark-hvilke konsekvenser har begrepsdefinitioner for den padagogiske praksis?" Paideia 5: 8-19.
[7] Haug, P. (2010). “Approaches to Empirical Research on Inclusive Education." Scandinavian Journal of Disability Research, 12(3), 199-209.

[8] Haug, P. (2017). Understanding inclusive education: ideals and reality.Scandinavian Journal of Disability Research, 19(3), 206217.

[9] Hogg, M., \& Vaughan, G. (2005). Social Psychology (4th ed). London: Prentice-Hall.

https://examplanning.com/definition-of-education-by-differentauthors/ accessed 05-02-2021.

https://www.tes.com/news/what-is-pedagogy-definition accessed 06-02-2021.

[10] Idol, L. (2006). Toward inclusion of special education students in general education: A program evaluation of eight schools. Remedial and Special Education, 27, 77-94.

[11] Juvonen, J. Lessard, L. M., Rastogi, R., Schacter, H. L, \& Smith, D. S. (2019). Promoting Social Inclusion in Educational Settings: Challenges and Opportunities. Educational Psychologist,54(4), 250-270.

[12] Katz, D. (1960). Public opinion quarterly. 24, 163-204.

[13] Killoran, I., Woronko, D., \& Zaretsky, H. (2014). Exploring Preservice Teachers' Attitudes Towards Inclusion. International Journal of Inclusive Education, 18(4), 427-442.

[14] Koster, M., Pijl, S. J., Nakken, H., \& Van Houten, E. (2010). Social participation of students with special needs in regular primary education in the Netherlands. International Journal of Disability, Development and Education, 57(1), 59-75.

[15] Markova, M., Cate, I. P., Krolak-Schwerdt, S., \& Glock, S. (2015). Preservice Teachers' Attitudes Toward Inclusion and Toward Students with Special Educational Needs from Different Ethnic Backgrounds. The Journal of Experimental Education, 1-25.

[16] McCain, H. (2017). Living with Disability and Chronic Pain Presented by Creating Accessible Neighbourhoods: Medical Model of Disability versus Social Model of Disability. Accessed https://canbc.org/blog/medical-model-of-disability-versus-socialmodel-of-disability/

[17] McLeod, S. A. (2018). Attitudes and behavior. Simply Psychology. https://www.simplypsychology.org/attitudes.html accessed 02-01-2021.

[18] Moberg, S., Muta, E., Korenaga, K., Kuorelahti, M., \& Savolainen, H. (2019). Struggling for inclusive education in Japan and Finland: teachers' attitudes towards inclusive education. European Journal of Special Needs Education.

[19] Mosia, P., A. (2014). Threats to inclusive education in Lesotho: An overview of policy and implementation challenges. Africa Education Review 11(3).

[20] National Center on Educational Restructuring and Inclusion (NCERI). (1995). National study of inclusive education. New York: University of New York Press.

[21] OECD. (2012). Education today 2013: The OECD perspective. OECD Publishing. Retrieved from http://dx.doi.org/10.1787/edu today-2013-en.

[22] Organization for Economic Co-operation and Development (OECD) (1999). Inclusive Education at Work. Paris: OECD.

[23] Sakari, M., Etsuko, M., Kanako, K., Matti, K. \& Hannu, S. (2019): Struggling for inclusive education in Japan and Finland: teachers' attitudes towards inclusive education, European Journal of Special Needs Education.

[24] Schmidt, M., Krivec, K. \& Bastič, M. (2020). Attitudes of Slovenian parents towards pre-school inclusion. European Journal of Special Needs Education,

[25] Schwab, S. (2017). The Impact of Contact on Students' Attitudes Towards Peers with Disabilities. Research in Developmental Disabilities, 62, 160-165.

[26] Sharma, J. (2019). Parents' Attitudes to Inclusive Education: A Study Conducted in Early Years Settings in Inclusive Mainstream Schools in Bangkok, Thailand. International Journal of Special Education, 33(4).

[27] Shipley, W. W. (1995). Duck! Someone said, 'Inclusion'! Reactions to a survey (Washington, DC, US Department of Education). 
[28] Shyman, E. (2015). Toward a Globally Sensitive Definition of Inclusive Education Based in Social Justice. International Journal of Disability, Development and Education, 62(4), 351-362.

[29] Smith, A., N. (1971). The importance of attitude in foreign language learning. Modern Language Journal, 55(2), 83-88.

[30] Snyder, R. (1999). Inclusion: A qualitative study of in-service general education teachers' attitudes and concern. Chulavista. Project Innovation. 173-180.

[31] Steele, J., Holbeck R., \& Mandernach, J. (2019).Defining Effective Online Pedagogy. Journal of Instructional Research, $8(2), 5-8$.

[32] Sunko, E. (2006). Perspectives of students of teacher education on the integration and inclusion of children with special needs. Progress, 147(2), 209-221.

[33] Swart, E., Engelbrecht, P., Eloff, I., Pettipher, R. \& Oswald, M. (2004). Developing inclusive school communities: Voices of parents of children with disabilities. Education as Change, 8(1), $80-108$.

[34] United Nations Educational, Scientific and Cultural Organization (UNESCO). (1994, June 7-10). The UNESCO Salamanca Statement. Adopted by the World Conference on special needs education: http://www.csie.org.uk/inclu sion/unescosalamanca.shtml accessed 05-02-2021.

[35] United Nations International Children's Emergency Fund (UNICEF) (2017, September). Inclusive education.Including children with disabilities in quality learning: what needs to be done?

[36] Vislie, L. (2003). "From Integration to Inclusion: Focusing Global Trends and Changes in the Western European Societies." European Journal of Special Needs Education, 18(1), 17-35.

[37] Zelina, M. (2020). Interviews with Teachers about Inclusive Education. Acta Educationis Generalis, 10(2), 95-111. 